\title{
The Relationship between Grammatical Knowledge and the Ability to Guess Word Meaning: The Case of Iranian EFL Learners with Upper Intermediate Level of Proficiency
}

\author{
Mehnoosh Ranjbar \\ Islamic Azad University, Shahreza branch, Isfahan, Iran \\ Email: r_mehnoosh@yahoo.com
}

\begin{abstract}
The present study provided some empirical data to examine the contribution of grammatical knowledge to getting the meaning of unknown words. The researcher's aim was to see if grammatical knowledge played any significant role in word guessing. For this purpose, thirty participants took part in this study. To evaluate their knowledge of grammar a sixty- item test of Nelson was given to them. Then a fortyfive item test on vocabulary was administered to see how grammar knowledge can affect their ability in guessing. The findings indicated that grammar knowledge was a key factor in deciphering the meanings of unknown words. It was also shown that the more comprehensive the grammar knowledge was, the higher the learners' proficiency level in guessing words would be. Therefore, instruction of grammatical structures in L2 contexts is recommended.
\end{abstract}

Index Terms—-grammatical knowledge, word meaning, EFL learners, vocabulary learning

\section{OVERVIEW}

The ability to decipher the meaning of the text (both written and spoken) is one of the most important skills required of people in second and foreign language settings. Today we face lots of input (written and spoken) in our daily life. A great amount of this input is unknown to us; therefore, we need to guess. Any understanding of reading texts and knowing the utterances require close attention to a number of factors, one fundamental factor of which is the knowledge of grammar (Nassaji, 2004).

Knowing words is the key to understanding as well as being understood, and the bulk of learning a new language consists of learning new words. Since we are faced with lots of new vocabulary items in our reading and listening, one helpful technique is to guess the meaning of unknown words. In many cases this attempt fails because of the lack of our knowledge regarding the grammatical structure of the sentences (Anderson, 1991).

To illustrate how learners deal with unknown words, Read (2000) refers to initial evaluation of the unknown word in terms of its contribution to the general understanding of the texts. Learners normally evaluate the contribution of the unknown words to their general understanding. If an unknown word is not regarded as exerting a major influence on comprehension, it is normally ignored; on the other hand, if it is judged to greatly contribute to determining the meaning, a variety of strategies are used to disambiguate it. Most often learners tend to infer the meaning of unknown words from context. As Read (2000) suggests, this is considered desirable on the grounds that "it involves deeper processing that is likely to contribute to better comprehension of the text as a whole and may result in some learning of the lexical item that would not otherwise occur" (p. 53).

Learning to read in a second language is one of the most valuable skills L2 learners should develop for social and academic purposes. This makes reading an active process and a demanding skill as readers are required to use the background knowledge, the grammatical knowledge, the situational context and the contextual clues to construct an interpretation of the meaning of a text (Brantmerier, 2003b; Pritchard, 1990). As such a growing body of research on reading has focused on how readers:

a) Utilize background knowledge to construct a model of text (e.g., Brantmerier, 2003b; Johnson, 1982; McNamara et al., 1996; Pritchard, 1990);

b) Use L2 grammatical knowledge to understand text (e.g., Alderson \& Urquhart, 1984; Anderson, 1984; Brantmerier, 2003b; Hammandou -Sullivan, 1991) and

c) Employ strategies to comprehend texts (e.g., Frantzen, 2003; Laufer, 1997; Young \& Oxford, 1997).

The influence of background knowledge on reading comprehension has been investigated extensively. Differences in prior knowledge affect the usefulness of different resources available to learners resulting in degrees of learning. The facilitating effect of background knowledge on reading comprehension has been demonstrated in some ways. 


\section{StAtement OF THE Problem}

Words are the basic units of the language without them one cannot express ideas effectively. Having a limited vocabulary is also a barrier that prevents students from learning a foreign/second language. If learners do not know how to expand their vocabulary, they gradually lose interest in learning.

Research has shown that intermediate and advanced EFL learners guess their vocabulary to a great extent through adjacent words and grammatical structure of the sentence. Readers' vocabulary knowledge is indeed an essential prerequisite for inferencing (Barnett, 1989; Huckin \& Coady, 1999; Kelly, 1990). When readers come across unknown words they may be unable to make use of available contextual clues due to the unknown nature of the words that may be used to disambiguate an unknown word. Thus, usable context is affected by the proportion of known to unknown words; when there exists a large proportion of unknown to known words, learners may be unable or reluctant to use contextual clues for inferencing word meaning.

Grammar knowledge has a significant impact on inferencing. The role of grammar in L2 learning and processing has been well acknowledged (Haastrup, 1991; Kelly, 1990; Paribakht, 2004; Paribakht \& Weshe, 1999). However, as Paribakht (2004) mentions, "it is far from clean how grammatical knowledge can assist learners in their L2 lexical processing and subsequent vocabulary acquisition" (p. 149). There are only few studies indicating that grammar knowledge is involved in L2 lexical processing (e.g., Paribakht, 2004; Paribakht \& Weshe, 1999). Concurring the view that grammar knowledge influences inferencing, Haastrup (1991) notes that "lexical inferencing involves making informed guesses as to the meaning of a word in light of all available linguistic cues in combination with the learners' general knowledge of the world, her awareness of the context and her relevant linguistic knowledge" (p. 40).

Lexical inferencing is the most frequently used strategy by EFL learners (Kaivanpanah, 2004; Oxford, 1990; Paribkht, 2004). Consequently, although an in-depth understanding of factors influencing inferencing may not only help us develop insights into the nature of comprehension processes, it may, as Paribakht (2004) suggests "shed some lights on the role knowledge of grammar may play in lexical processing' (p. 150). In this area, the main focus of this research would be whether grammatical knowledge has any impact on guessing words. Unfortunately, grammar teaching has always been one of the most controversial and least understood aspects of language teaching. Few teachers remain indifferent to grammar and many teachers have been obsessed by it.

Therefore, to contribute to the developing literature in the field, this research aimed at investigating the relationship between grammatical knowledge and the ability to guess word meaning among Iranian EFL learners with upper intermediate level of proficiency.

\section{OBJECTIVES OF THE STUDY}

A number of studies including Ellis (2008), Lantolf and Johnson (2007), Paribakht (2004), Kaivanpanah (2004), Nassaji (2004), Frantzen (2003), Brantmerier (2003a), Schmidt (2001), Gass (1988), and Long (1996) have been conducted so far around the world to see whether relationship between grammatical knowledge and the ability to guess word meaning among Iranian EFL learners with upper intermediate level of proficiency.

The review of previous studies suggests that few studies for this case has been conducted in the context of Iran. Therefore, the present study aimed at revealing some common barriers that hinder vocabulary learning among Iranian students and also determining the impact of grammar knowledge on the ability of guessing word meaning among Iranian EFL learners with upper intermediate level of proficiency.

\section{RESEARCH QUESTION}

To achieve the goals of this study, the following question was addressed:

Is there any meaningful relationship between the knowledge of grammar and the ability to guess word meaning?

\section{RESEARCH HYPOTHESIS}

To investigate the above research questions of the present study, the following null hypothesis is addressed:

$H_{01}$ : There is no relationship between grammar knowledge and the ability to guess word meaning.

\section{SigNifiCANCE OF THE STUDY}

When foreign language learners are confronted with an unfamiliar word through intensive or extensive L2 reading, they must decide how to handle the word. This can be accomplished in a variety of ways, which include ignoring the word, checking a dictionary for the word's definition, and attempting to infer the meaning. Specifically, this will focus on inferencing strategies in L2 reading. More specifically, it will identify different inferencing strategies, how effective these inferencing strategies are, what factors can influence the success of inferencing, and what this means for teaching inferencing strategies in the L2 classroom. Almost all literature on inferencing strategies distinguishes between strategies centered on the unfamiliar word itself and strategies that are contextually based.

The phrase global strategies were used to describe the contextually based inferencing strategies. However, these terms only represent the broadest definition of inferencing strategies. From their study on the role of linguistic 
knowledge, Kaivanpanah (2004) identified seven different inferencing strategies. The first strategy they found was sentence level grammatical knowledge, which involves looking for relationships between words to determine meaning. This strategy would fall under Hamada's idea of local strategies, where the focus is more on the word than contextual clues within the text.

According to Eliss (1991), the main reason for believing that lexical knowledge can help grammar acquisition is that knowledge of the words in a text permits learners to understand the meaning of the discourse which is in turn allows them to understand the grammatical patterning.

Among the factors the learners use in their guessing, grammatical knowledge is a vital one. A factor which has been less focused in the literature. When we go through textbooks we see a great number of them lack enough grammar practices that is due to the fact that is believed grammar is finite and it is not necessary to take it into our syllabus.

This study can probably establish a good relationship between the level of grammar knowledge and its role on word guessing so we see that knowledge of grammar is essential if the learners are supposed to read widely in the life.

\section{Methodology}

\section{A. Participants}

A multiple-choice proficiency test, (i. e., OPT), was administered. Thirty female students out of fifty were chosen from among EFL learners in Saee Institute in Isfahan in order to select a homogenous group with upper intermediate level of proficiency. This test consists of 60 multiple-choice items (OPT, 2005). It includes three different sections 20 grammar items, 20 reading items, and 20 vocabulary items.

\section{B. Materials}

In the present study, the materials were composed of three types of tests based on which the required data was collected.

\section{Vocabulary test}

The vocabulary test was an essay-type test which entailed one hundred and fifty words randomly chosen from Nelson tests. The words belonged to all parts of speech and were selected in a way that the students had not seen before. The words were then listed and the participants were asked to write a definition, a synonym, or an opposite for each in either English or Persian.

\section{Grammar Test}

The grammar test was a multiple choice test composed of sixty grammatical items chosen from Nelson tests as a source of data. The items belonged to different grammatical structures including tenses, conditional sentences and so on.

\section{Unknown Words in Context}

Out of one hundred and fifty words given to students to write their meanings, there were about seventy words for which none of the participants could suggest any meaning. Therefore, from these unknown words, forty five words were randomly chosen based on which another test was prepared. Actually, these words were contextualized through providing grammatical contexts. The purpose here was to see how grammatical knowledge of the learners could affect their ability to guess the words they previously could not define.

\section{Procedure}

In order to collect data for this study several steps were taken. First, a multiple-choice proficiency test, (i.e., OPT), was administered. Thirty female students out of fifty were chosen from among EFL learners in Saee Institute in Isfahan in order to select a homogenous group with upper intermediate level of proficiency.

In the next step, in order to fulfill the purposes of the study, three tests were prepared and conducted in a one week period. The first one was a one hundred and fifty word test. This test was in the format of an essay- type test. There were words with enough space provided. The students were asked to write the Persian equivalents, synonyms or opposites to indicate that they knew the meanings of the words. The time allocated for this exam was forty minutes. The aim of this exam was to extract the words which were unknown to all participants. After the exam, those correctly answered words were ticked. Since the unknown words were needed, a search was made for those words which nobody could answer. Then, seventy words were found as unknown to all participants. These words were listed and two days later, another test was conducted under the supervision of the researcher. It was a grammar test in a multiple choice format with the purpose of evaluating the students knowledge of grammar. To have a valid test, a test from Nelson was used. This test which had sixty items included varied grammatical structures as well as tenses, parts of speech, complex sentences, conditional and many more. The time allocation for this second test was thirty minutes.

Since the focus was to see if those students with a better knowledge of grammar could guess those words they had been unable to guess in a context free situation, the next step was to contextualize those words unknown to all participants. Forty five words from those eighty unknown words were selected randomly and each word was inserted in a distinct grammatical structure with the focused words underlined asking students to write the Persian equivalents, synonyms or opposites in the spaces provided. This test was also developed in an essay type and its allocated time was thirty minutes. 


\section{RESULTS}

For the purpose of data analysis, the descriptive accounts concerning the basic source of examined data was first provided through which one can have an overview of the learners' overall performance on both grammar and vocabulary tests. The scores were computed out of 60 for the grammar and 45 for the vocabulary test.

TABLE 1

DESCRIPTIVE STATISTICS FOR GRAMMAR AND VOCABULARY SCORES

\begin{tabular}{|l|l|l|l|l|l|}
\hline & $\mathrm{N}$ & Min & Max & Mean & SD \\
\hline Grammar Test & 30 & 40 & 56 & 46.26 & 4.16 \\
\hline Vocabulary Test & 30 & 30 & 42 & 35.00 & 3.0 \\
\hline
\end{tabular}

Accordingly, the performance of the learners in grammar was better than that of vocabulary with the former favoring a higher mean value of 46.26. Besides, the standard deviation values highlight the extent of variation that is higher for the grammar scores (4.16) and lower for the vocabulary scores (3.0). In other words, despite the scores variation on the grammar test, the learners' performance on the vocabulary test has been almost similar with the scores piled up around the mean. To examine the extent of correlation between the two sets of grammar and vocabulary data, it is primarily needed to ensure the existence of a linear correlation between the two variables. To this end, the following scatter plot was provided.

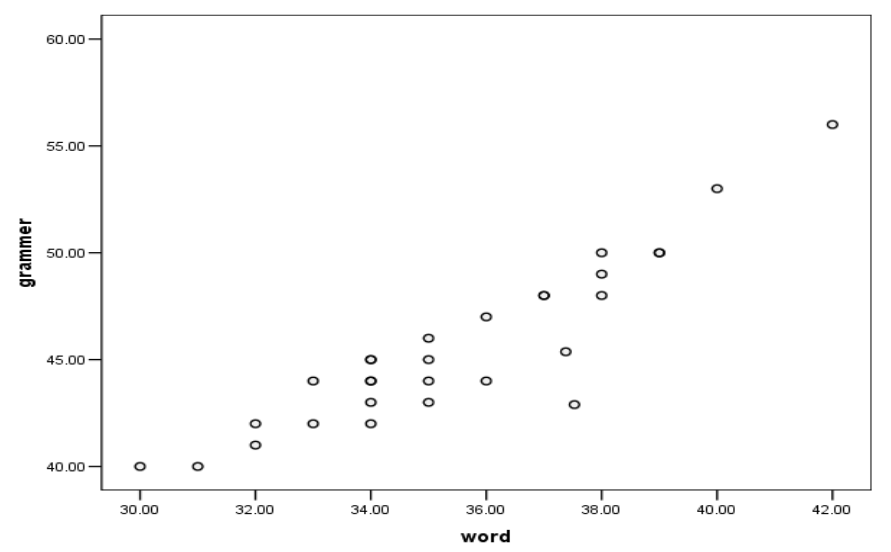

Figure 4.1. The Scatter Plot of Grammar and Vocabulary Scores

There appears to be a positive linear correlation between the two variables in a way that the more one knows grammar, the more successful his/ her vocabulary guessing will be.

Following the above graphic representation, the relationship between grammar knowledge and vocabulary guessing performance was investigated using Pearson product-moment correlation coefficient.

TABLE 4.2

THE CORRELATION BETWEEN GRAMMAR AND VOCABULARY SCORES

\begin{tabular}{|ll|l|l|}
\hline & Grammar & Vocabulary \\
\hline Grammar & Pearson Correlation & 1 & $.621^{* *}$ \\
& Sig. (2-tailed) & .000 \\
& $\mathrm{~N}$ & 30 & 30 \\
\hline Vocabulary & Pearson Correlation & $.621^{* *}$ & 1 \\
& Sig. (2-tailed) & .000 & \\
& $\mathrm{~N}$ & 30 & 30 \\
\hline
\end{tabular}

Accordingly, there was an almost strong, positive correlation between the two variables $[\mathrm{r}=.62, \mathrm{n}=30$, $\mathrm{p}<.05]$, with high levels of grammar knowledge associated with higher levels of success in guessing the meaning of vocabulary items, leading to rejection of the null hypothesis.

The following graph clearly suggests a detailed account of such differences in the participants' grammar and vocabulary performances. Clearly, lower levels of grammar knowledge have resulted in lower levels of proficiency in guessing meanings. At the same time, higher levels of grammar have ended in more successful vocabulary guesses. 


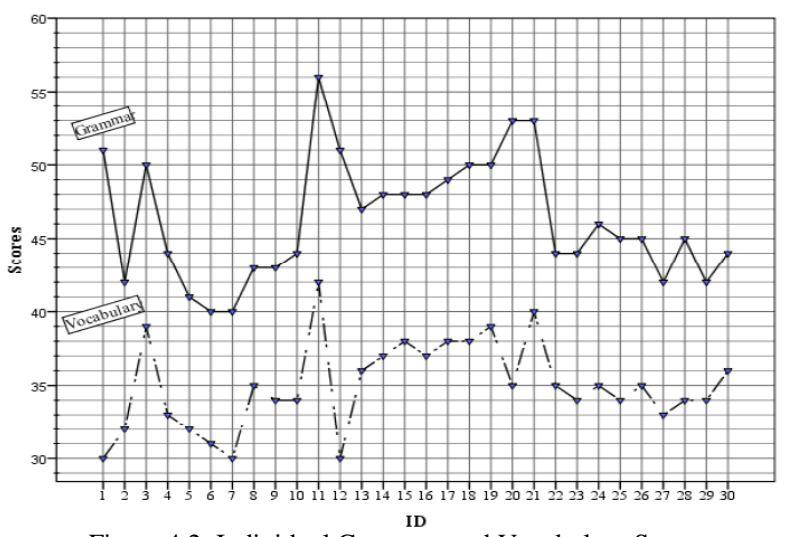

Figure 4.2. Individual Grammar and Vocabulary Scores

Meanwhile, the overall difference between the mean scores of these two sets of accounts is depicted through the higher position of grammar line in comparison with the vocabulary line.

As it was seen through analysis done using different statistical measures, the null hypothesis of the study which stated that:

1: There is no relation between grammar knowledge and the ability to guess word meaning can safely be rejected. Put it another way, it can be said that:

2: Apparently there is relation between grammar knowledge and the ability to guess word meaning.

\section{Discussion}

The study described in this paper set out to answer one question regarding whether there is any relationship between grammar knowledge and the ability to guess word meaning.

Concerning the research question, the findings displayed that the knowledge of grammar improves the ability to guess word meaning. This kind of knowledge helps not only vocabulary acquisition but also vocabulary guessing. As learners encountered new contexts, a large number of newly met words appear. Different methods are taken into account to succeed in getting their meanings. Unfortunately, the importance of grammar in L2 teaching and learning has been ignored for many reasons. The fact shows that grammar can help learners in many aspects because it serves as a tool to self-correct and self-edit the utterances we produce or receive in our daily life. Grammar in its broadest sense means knowledge of vocabulary formation and knowledge of sentence formation.

The findings of the study in hand are in line with the findings of other scholars doing research in this are including Parel (2004) also found that high school beginning-level ESL learners' morphological knowledge led to successful meaning-inference and even compensated for their limited vocabulary knowledge in reading comprehension.

Other scholars (Nassaji, 2006; Paribakht \& Wesche, 1999), believe lexical inferencing has been found to be widely used by L2 learners when dealing with unknown words and it has been closely associated with incidental vocabulary learning. For Paribakht and Wesche (1999), much lexical development in both L1 and L2 appears to occur as learners attempt to comprehend new words they hear or read in context.

Some professionals active in the field under study believe that Grammar knowledge has a significant impact on inferencing. The role of grammar in L2 learning and processing is well acknowledged (Haastrup, 1991; Kelly, 1990; Paribakht, 2004; Paribakht \& Weshe; 1999). These studies are also in line the findings presented in the reference section.

Also other figures active in presenting theories in EFL/ ESL also believe lexical inferencing is the most frequently used strategy by EFL learners (Kaivanpanah, 2004; Oxford, 1990; Paribkht, 2004). Consequently an in-depth understanding of factors influencing inferencing may not only help us develop insights into the nature of comprehension processes, it may, as Paribakht (2004) suggests, "shed some lights on the role knowledge of grammar may play in lexical processing" (p. 150).

Again as it can be inferred from the very brief evidence provided that grammar knowledge can make significant difference in guessing word meaning.

To sum up, knowledge of grammar has proved a vital effect in guessing meaning. It means that grammar is a very important factor in deciphering the meanings of unknown words in a text. Moreover, the more comprehensive the grammar knowledge is, the higher the learners' proficiency level in guessing words will be. Therefore, it appears useful to put more focus on grammar teaching in the pedagogical settings so that it enhances language learning in all aspects.

\section{Conclusion}

In the discussion about the role and importance of word meaning guessing in second language instruction, the knowledge sources L2 learners draw upon have not been addressed properly. The present study was an attempt to 
remedy this dearth of research and offer insights into the way grammar knowledge influences word meaning guessing. It is of utmost importance that language teachers spend more class time on familiarizing learners with grammatical constructions and text structure through explicit and implicit grammar instruction. Word meaning guessing is promoted on the assumption that there are available clues in the context to help learners infer the meaning of unknown words. If the context does not provide proper clues for word meaning guessing, teacher should motivate students to use external clues to infer. To get a better skill at word meaning guessing, one useful practice is to teach learners to check the accuracy of their guessing in a dictionary. The analysis of errors learners make while guessing meaning may shed some lights on how readers process texts and what can be done to assist them.

We can conclude that guessing the meaning of words and structures is a skill which needs some practice and knowledge. Our word meaning guessing is influenced by some factors including context clues and co-text clues. We need both clues at our disposal to get the unknown words across. One fundamental factor is the knowledge of grammar and structure of the sentences. This kind of knowledge whether acquired implicitly or explicitly, is essential for all aspects of language learning especially for guessing the components of a larger block.

\section{IMPLICATIONS OF THE STUDY}

The importance of vocabulary learning is obvious to almost all educationalists and learners. This is the first thing which a foreign learner encounters while entering the class. They have to deal with words in many different ways. Also, they have to memorize the words for their communication. But the importance of grammar in a foreign setting has been overlooked by many experts and learners. They do not know the value of grammar and its role in learning a foreign language. Perhaps, this is the case because of the way grammar is taught. Instead of throwing grammar away from our books and our syllabus, we as teachers and scholars should find some new methods and ways to teach grammar in a fun and lively manner.

Teaching grammar is said to be boring because I think this teaching does not aim at an communicative goal. Grammar is a tool like words for communication. To have a better command on our communication with other speakers we must develop not only our word power but also our grammar power. This grammar gives us chances to use words effectively and efficiently in our speech and our writing.

As was mentioned before, grammar is a sub skill which can have vital impact on other skills. Language without grammar is a list of words. Words by themselves are not enough communicative to transfer meanings and messages. My final word is that pedagogical grammar is necessary and should be an essential part of our syllabus.

\section{LIMITATIONS OF THE STUDY}

In the course of this study, there were several sources of limitation which exerted influence in a way to delimit the progressive nature of the findings.

For one thing, lack of a rich literature in dealing with the same subject at stake was one of the major shortcomings in this field. In other words, there was a lack of comprehensive helpful studies on investigating the relationship between grammatical knowledge and the ability to guess word meaning among Iranian EFL learners.

A second limitation of this study directly goes to the accessibility issue in terms of the participants. It appeared really difficult to find the appropriate number of students to have a random selection out of this larger group. If the sample were larger, the generalizability of findings would be in a better position. Due to this fact, a word of caution should be taken in to account in generalizing the results.

Finally, evaluation of grammatical and meaning guessing skills is not free of certain limitations.

\section{SUGGESTIONS FOR FURTHER RESEARCH}

Based on the present findings it is understood that grammar has a key factor in learning a foreign language. It helps learners to acquire an ability to guess the meanings of unknown words. Within a context there are so many factors which can help our success in guessing meaning. Other researchers should take a step to investigate other elements which can have an effect on word knowledge. We understand that grammar knowledge leads to vocabulary acquisition. A research should be done to see if vocabulary learning leads to grammar acquisition or not. SLA researchers should take this topic into their consideration and work on such an area. Therefore, further work on developing tests of these two knowledge types is still waiting to be addressed.

\section{APPENDIX A VocABULARY LIST}

$\begin{array}{llll}\text { 1. private } & \text { 2. someone else } & \text { 3. rent } & \text { 4. appointment } \\ \text { 5. surface } & \text { 6. ask for } & \text { 7. turn up. } & \text { 8. cost } \\ \text { 9. record } & \text { 10. earning } & \text { 11. popular } & \text { 12. mistake } \\ \text { 13. occur } & \text { 14. way } & \text { 15. race } & \text { 16. satisfactory } \\ \text { 17. forecast } & \text { 18. go over } & \text { 19. notice } & \text { 20. chance } \\ \text { 21. foreign } & \text { 22. signature } & \text { 23. make up } & \text { 24. order }\end{array}$




$\begin{array}{ll}\text { 25. presently } & \text { 26. intend } \\ \text { 29. grateful } & \text { 30. crust } \\ \text { 33. take off } & \text { 34. beat } \\ \text { 37. beach } & \text { 38. disappointed } \\ \text { 41. grow up } & \text { 42. reach } \\ \text { 46. prevent } & \text { 47. strange } \\ \text { 50. amazed } & \text { 51. excited } \\ \text { 53. crash } & \text { 54. Nearby } \\ \text { 57. ride } & \text { 58. embarrassed } \\ \text { 61. stand for } & \text { 62. get over } \\ \text { 65. recovery } & \text { 66. threatened } \\ \text { 69. out of condition } & \text { 70. run down } \\ \text { 73. fold } & \text { 74. advise } \\ \text { 77. material } & \text { 78. hostel } \\ \text { 81. break up } & \text { 82. make out } \\ \text { 85. suit } & \text { 86. label } \\ \text { 89. vase } & 90 . \text { at first } \\ \text { 93. go on } & \text { 94. take advantage } \\ \text { 97. in short } & \text { 98. in effect } \\ \text { 101. go in } & \text { 102. hold up } \\ \text { 105. rusty } & \text { 106. rent } \\ \text { 109. plan } & \text { 110. attend } \\ \text { 113. bend } & \text { 114. shortage } \\ \text { 117. break out } & \text { 118. take over } \\ \text { 121. slip } & \text { 122. lecture } \\ \text { 125. installment } & \text { 126. come up } \\ \text { 129. put off } & \text { 130. break off } \\ \text { 133. trap } & \text { 134. turn out } \\ \text { 137. power } & \text { 138. common } \\ \text { 141. opponent } & \text { 142. go off } \\ \text { 145. harm } & \text { 146. purpose } \\ \text { 149. pipe } & \text { 150. relatives } \\ & \\ & \end{array}$

\begin{tabular}{|c|c|}
\hline 27. advertise & 28. apply \\
\hline 31. afraid & 32. turn up \\
\hline 35. floor & 36. stay \\
\hline 39. boring & 40. expect \\
\hline 43. wear & 45. fare \\
\hline 48. notice & 49. trouble \\
\hline 52. look up & 53. carry on \\
\hline 55. favorite & 56. deal with \\
\hline 59. conductor & 60. keep \\
\hline 63. glance & 64. custom \\
\hline 67. figures & 68. sack \\
\hline 71. see off & 72. come up \\
\hline 75. member & 76. apologized \\
\hline 79. on arrival & 80. keep on \\
\hline 83. wrap & 84. survive \\
\hline 87. illness & 88. regret \\
\hline 91. in advance & 92. do up \\
\hline 95. owe & 96. scratch \\
\hline 99. to some extent & 100. consent \\
\hline 103. run over & 104. reward \\
\hline 107come round & 108. take in \\
\hline 111. run out of & 112. accuse \\
\hline 115. assure & 116. modern \\
\hline 119. recipe & 120. clerk \\
\hline 123. Respectable & 124. review \\
\hline 127. occasion & 128. persist \\
\hline 131. bring up & 132. retire \\
\hline 135. teach & 136. get over \\
\hline 139. take after & 140. breed \\
\hline 143. look down & 144. signal \\
\hline 147. agree & 148. layer \\
\hline
\end{tabular}

\section{ApPendix B The Grammar Test}

Choose the best answer.

First name teacher:

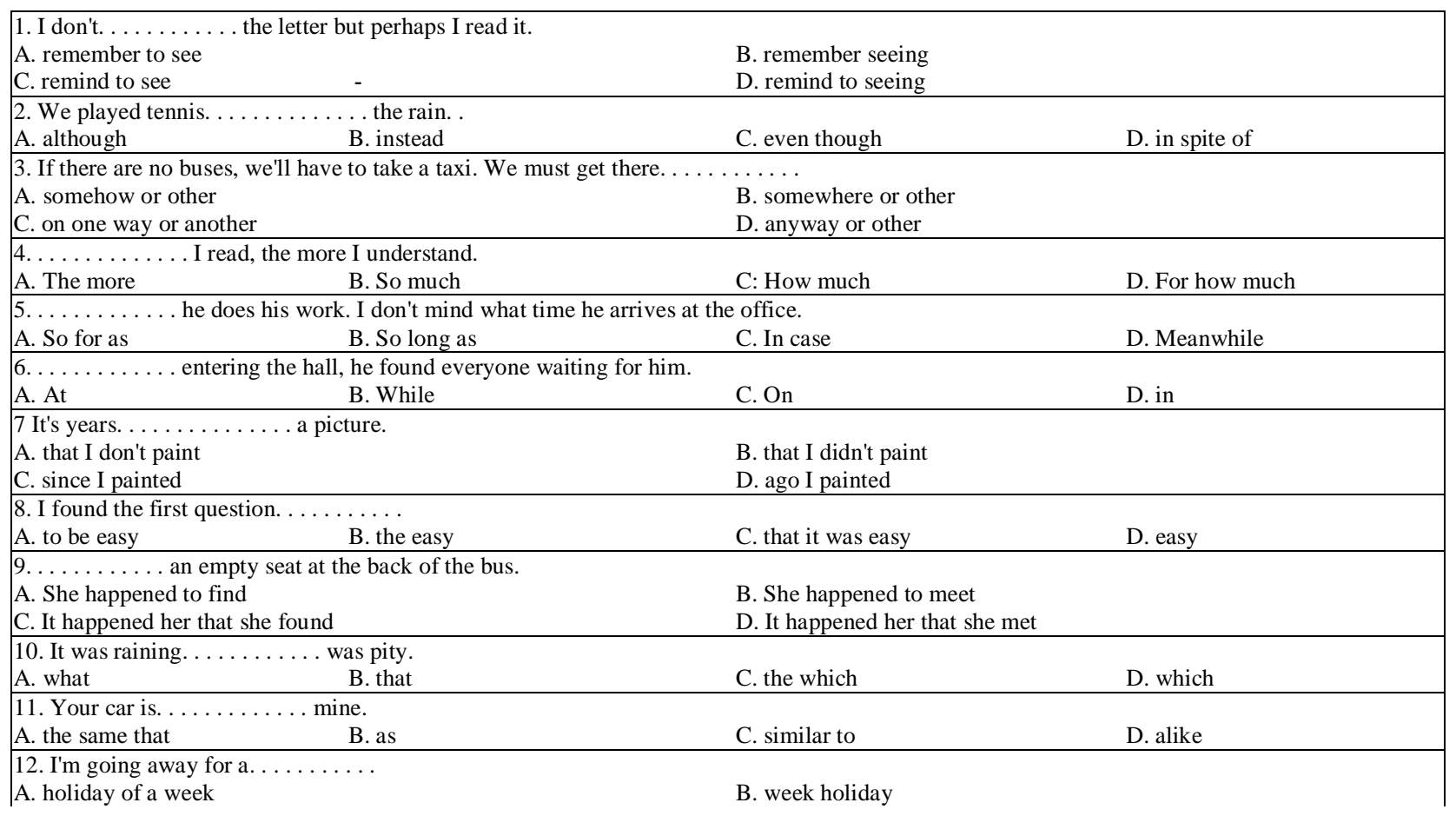


C. Holiday week D. Week's holiday

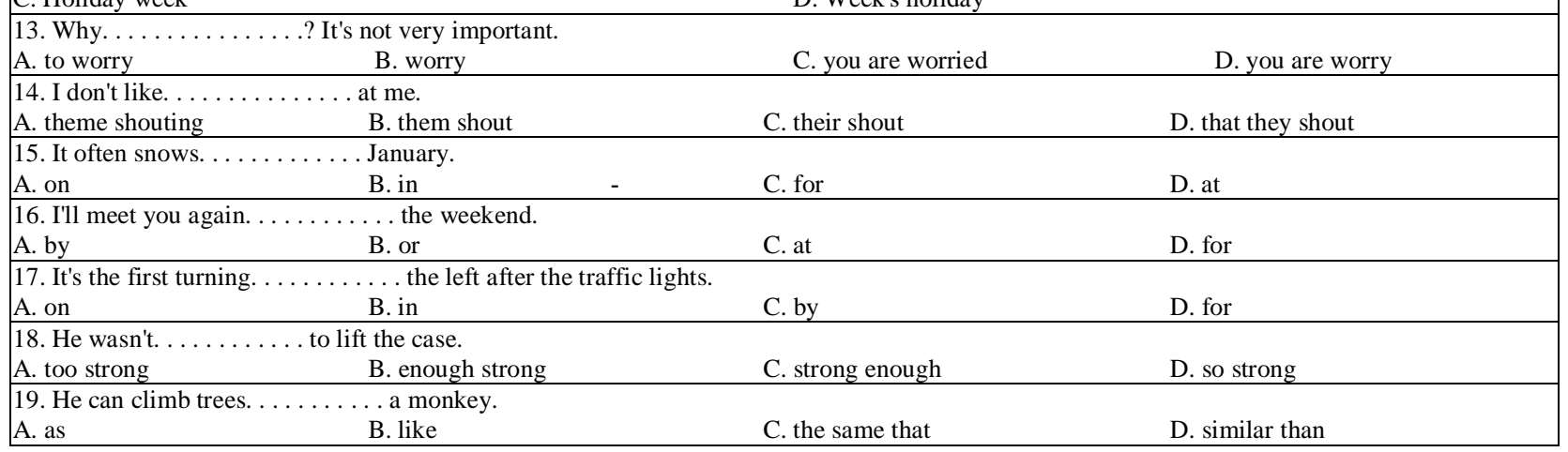

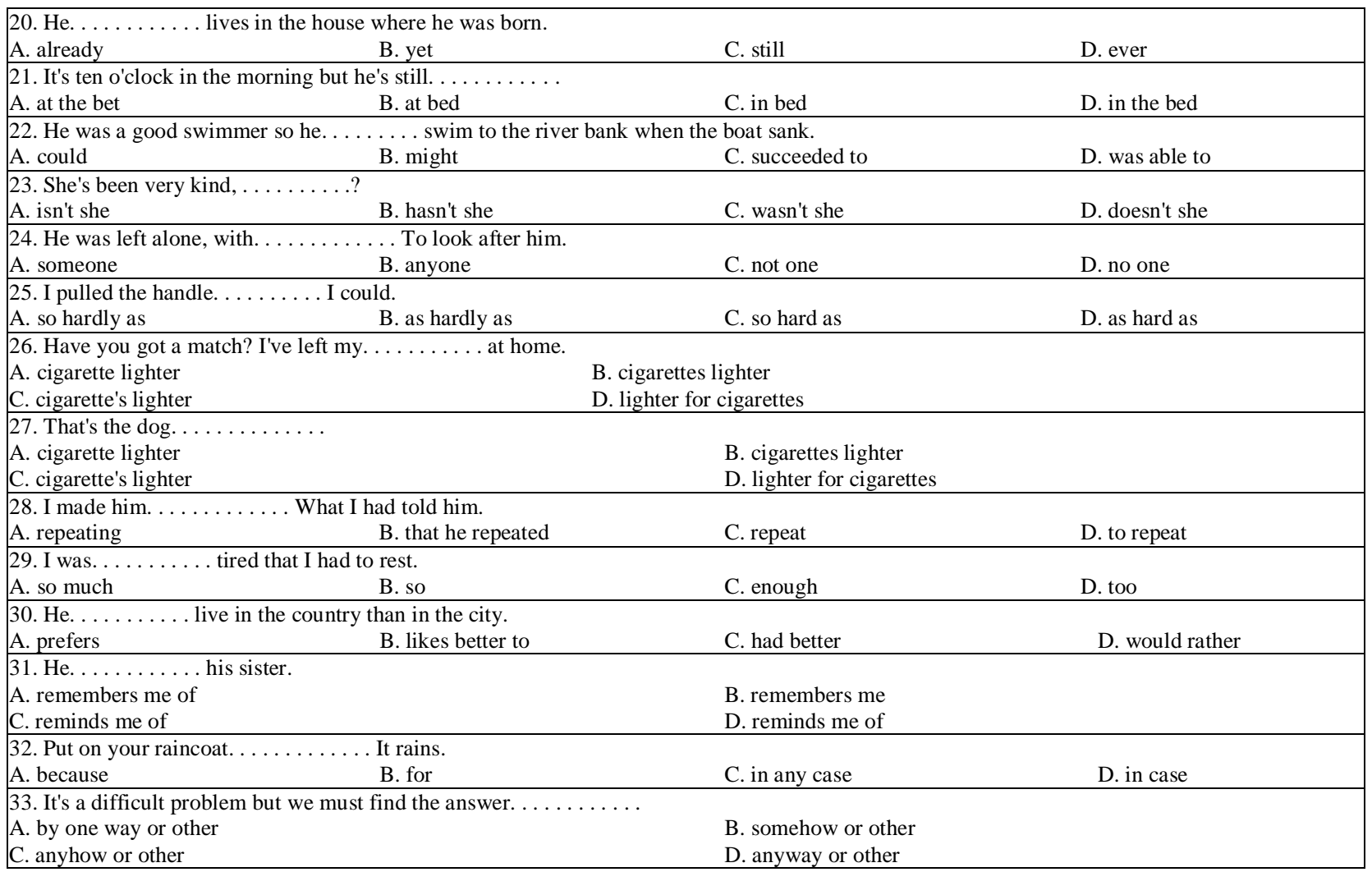

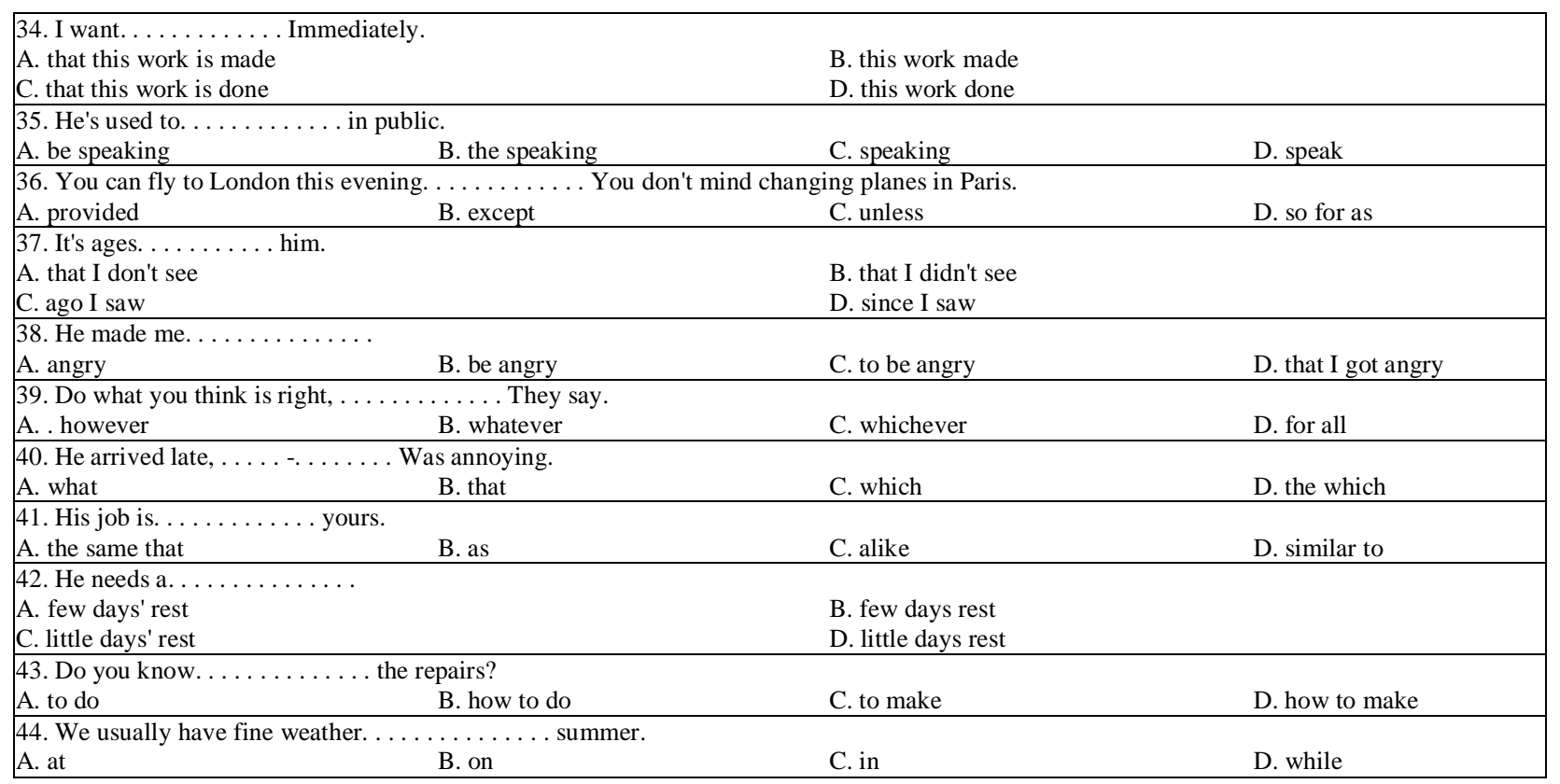




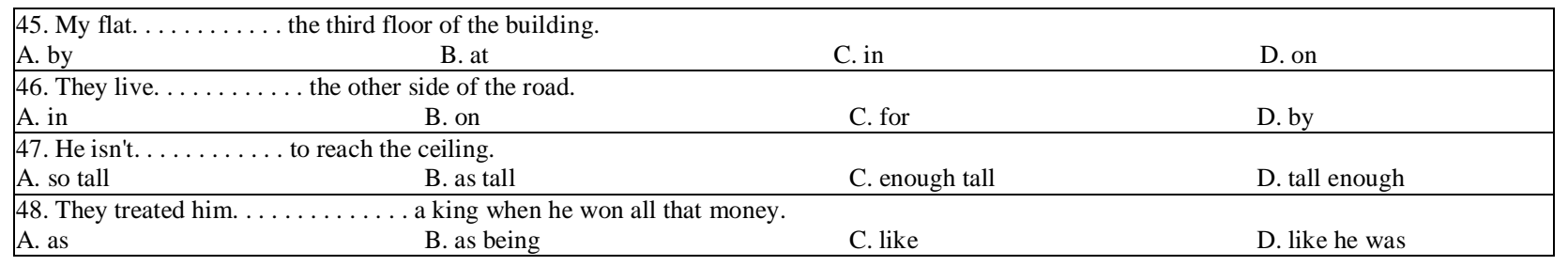

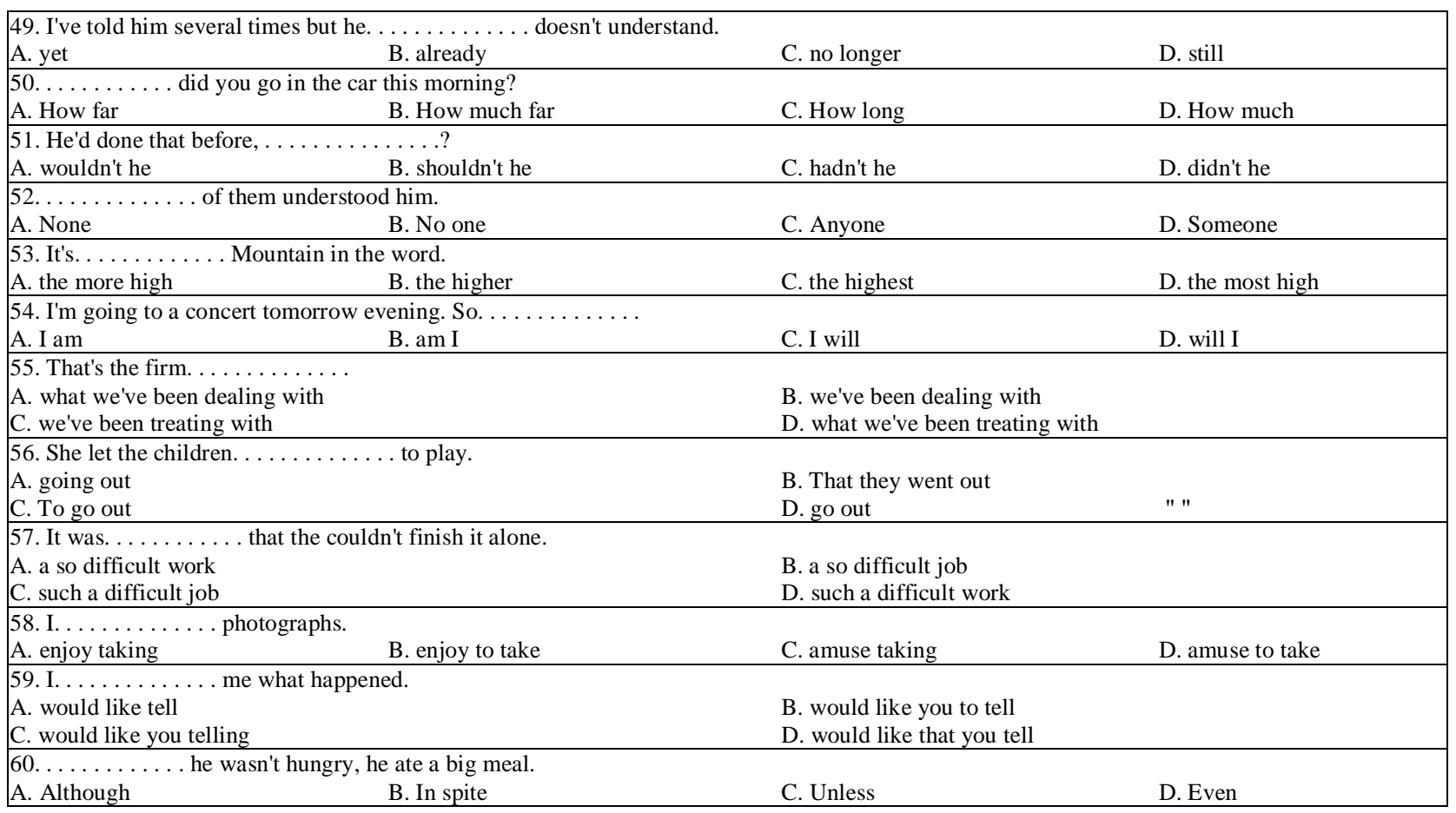

\section{APPENDIX C WORDS IN CONTEXT}

Write the meanings of the underlined words in English or persion in the space provided.

1. The weather forecast says it will rain tomorrow ---------.

2. There are a lot of mistakes in this exercise. I will have to go over it again with you

3. I am very grateful to you for your help

4. He is so mean that he would not give a beggar a crust of bread -

5. I never expected you to turn up at the meeting. I thought you were abroad

6. He will soon get over his disappointment and be quite cheerful again by the morning ----.--

7. He glanced out of the window for a moment and then went on working ---------.

8. He is been working too hard and he is run down. He needs a rest ---------.

9. New problems are always coming up in the factory ---------.

10. he folded the letter carefully before putting it in the envelope

11. He is staying in the youth hostel in Market Street ---------.

12. The meeting broke up at midnight and we all went home

13. He is not as honest as he makes out

14. Everyone else was killed in the accident. I was the only one to survive

15. I will put the flowers in this vase. They will look nice there --------.

16. We are going to have our house done up. The decorators are coming next week --------.

17. He was sacked from the firm because he was always late for work ----------.

18. She got married although her parents had not given her their consent

19. I agree with him to some extent, but not entirely----------.

20. The dog was run over by a bus and killed ---------.

21 . Don't leave your bicycle out in the rain It will get rusty

22. He has been accused of murdering his wife ---------.

23. I assure you that the goods will be delivered next week

24. The Second World War broke out in 1939

25. A foreign firm have bought the shares in his company and taken it over

26 . He bought his house on the instalment plan, paying a certain a mount of money each month 
27. We can never relax in this office. new problems are coming up

28. If you persist in taking this attitude, we will have to ask you to leave ----------.

29. He talked so much during the match that he put me off my game --------.

30 . He broke off his engagement just before the wedding --------..

31. His parents died when he was young so he was brought up by his uncle -

32 . When he retires at the age of 65 , the company will give him a gold watch

33. The elephant fell into the trap the hunters had set for it -------.

34. The weather forecast was good so it should turn out fine after all ---------.

35 . He will get over his nervousness once he is on stage --------.

36 . This breed of dog is very useful for hunting --------

37. He shook hands with his opponent before the match

38. If you forgot to put the cheese in the refrigerator, it may go off

39. She looks down on us because she went to an expensive school

40. One of the water pipes has burst and the kitchen is full of water --.--.-.-.

41. I approved of his course of action, so I told him to go ahead ---------.

42. Close the door please. I don't like sitting in a draught

43. He scratched his head, wondering how to solve the problem

44. I owe him some money and must pay him back him tomorrow

45. The flight was supposed to take off at eight o'clock but in effect we had to wait until nine

\section{REFERENCES}

[1] Alderson, J. C. \& Urquhart, A. H. (Eds.) (1984). Reading in foreign language. London: Longman.

[2] Anderson, N. J. (1991). Individual Differences in strategy use in second language reading and testing. Modern Language Journal, 75, 460-472.

[3] Barnett, M. (1989). More than Meets the Eye. New Jersey: Prentice Hall Regents.

[4] Brantmeier, C. (2003a). The role of gender and strategy use in processing authentic written input at the intermediate level. Hispania, 86(4), 844-856.

[5] Brantmeier, C. (2003b). Beyond linguistic knowledge: Individual differences in second language reading. Foreign Language Annals, 36(1), 33-44.

[6] Ellis, R. (1991). Grammar teaching- practice or consciousness-raising. In R. Ellis (Ed.), Second language acquisition and second language pedagogy. Clevedon: Multilingual Matters.

[7] Ellis, R. (2008). The study of second language acquisition ( $2^{\text {nd }}$ ed.). Oxford: Oxford University Press.

[8] Frantzen, D. (2003). Factors affecting how second language Spanish students drive meaning form context, The Modern Language Journal, 87(ii), 168-199.

[9] Gass, S. (1988). Integrating research areas: A framework for second language studies. Applied Linguistics, 9, $198-217$.

[10] Haastrup, K. (1991). Lexical inferencing procedures or talking about words, Gunter Narr, Tübingen.

[11] Hammandou-Sullivan, J. (1991). Interrelationship among prior knowledge, inference, and language proficiency in foreign language reading. Modern Language Journal, 75, 27-38.

[12] Huckin, T. \& Coady, J. (1999). Incidental vocabulary acquisition in a second language acquisition: A review. Studies in Second Language Acquisition, 21, 181-193.

[13] Johnson, P. (1982). Effects on comprehension of building background knowledge. TESOL Quarterly, 16, 503-516

[14] Kaivanpanah, S. (2004). Guessing word-meaning: How reliable learners' assessments are? Paper presented at 11th TESOL Arabia convention. UAE, Dubai.

[15] Kelly, P. (1990). Guessing: no substitute for systematic learning of lexis. System, 18(2), 199-207.

[16] Lantolf, J. P., \& Johnson, K., (2007). Extending Firth and Wagner's 1997 ontological perspective to L2 classroom praxis and teacher education. Modern Language Journal, 91, 877-892.

[17] Laufer, B. (1997). The lexical plight in second language reading: words you don't know, words you think you know, and words you can't guess. In J. Coady, \& T. Huckin (Eds.), Second language vocabulary learning (pp. 20-34). Cambridge: Cambridge University Press.

[18] Long, M. H. (1996). The role of the Linguistic environment in second language acquisition. In W. C. Richie, \& T. K. Bhatia (Eds.), Handbook of language acquisition: Second language acquisition (vol. 2) (pp. 413-468). San Diego, CA: Academic Press.

[19] McNamara, D. S., Kintsch, E., Songer, N. B. \& Kintsch, W. (1996). Are good texts always better? Text coherence, background knowledge, and levels of understanding in learning from text. Cognition and Instruction, 14, 1-43

[20] Nassaji, H. (2004). The relationship between depth of vocabulary knowledge and L2 learners' lexical inferencing strategy use and success. The Canadian Modern Language Review, 61, 107-134.

[21] Oxford, R. (1990). Language learning strategies: What every teacher should know. New York: Newbury House Publisher.

[22] Parel, R. (2004). The impact of lexical inferencing strategies on second language reading proficiency. Reading and Writing: An Interdisciplinary Journal, 17, 847-873.

[23] Paribakht, T. S. (2004). The role of grammar in second language learning processing. RELC 35(2), 149-160.

[24] Paribakht, T. S., \& Wesche, M. (1999). Reading and incidental L2 vocabulary acquisition. An introspective study of lexical inferencing. Studies in Second Language Acquisition, 21, 195-218.

[25] Pritchard, R. (1990). The effect of cultural schemata on reading processing strategies. Reading Research Quarterly, 25(4), 273 295. 
[26] Read, J. (2000). Assessing vocabulary. Cambridge: CUP.

[27] Schmidt, R. (2001). Attention. In P. Robinson (Ed.), Cognition and second language instruction. Cambridge: Cambridge University Press.

[28] Young, D. J., \& Oxford, R. (1997). A gender-related analysis of strategies used to process input in the native language and a foreign language. Applied Language Learning, 8, 43-73.

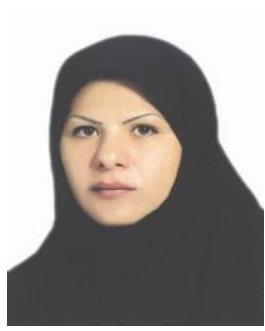

Mehnoosh Ranjbar was born in Isfahan, a beautiful city in Iran. She is an English teacher and lives in Iran. She received her BA degree in the field of translation at Kashan university and MA degree in the field of teaching at Shahreza University. 